\title{
Company towns and the governmentality of desired identities
}

Moonesirust, Elham (contact)

Elham.Moonesirust@abdn.ac.uk

University of Aberdeen Business School

MacRobert Building, Kings College

Aberdeen

AB24 5UA

UK

Brown, Andrew D.

School of Management

University of Bath

Claverton Down

Bath

BA2 7AY

UK

\section{Abstract}

How do people living in a company town come to desire to work for the firm that controls it? Based on an in-depth case study of Volkswagen in Wolfsburg, Germany, we make two principal contributions. First, drawing on Foucault's concept of governmentality we investigate the mechanisms of power within which desired identities are shaped. Desired identities, we argue, are one means by which organizations exercise control over local populations. Second, we examine the multiple interlocking discourses by which Volkswagen sought to regulate the life of Wolfsburgers and to form their desired identities. In doing so, we contribute to identity research by demonstrating how biopower and discipline work in combination in neoliberal societies to make the governmentality of employee identity possible. Our research underlines the importance of studying company towns for understanding the relations of power that shape the lives and the identities of employees. 


\section{Keywords}

Desired identities, governmentality, Volkswagen, discourse, biopower, disciplinary power, company town, neoliberalism 


\section{Introduction}

'What I see is that my life is completely determined by VW. I live in this city, in the VW-City. All the amenities and possibilities that I have here exist because of VW. These are only possible through VW' (Timothy).

'You can see Volkswagen almost from all parts of the city. You work there, you have relatives who work there, almost $90 \%$ of the cars you see on the streets are Volkswagen, you read about it in newspapers, of course you get influenced. You are basically always at Volkswagen' (Michael).

In 1938 a new city, later called Wolfsburg, was created to accommodate the workers of the car factory renamed Volkswagen after WWII. For over seventy years, Volkswagen (VW) and the city $^{1}$ of Wolfsburg have thrived. Today, a significant majority of the citizens of Wolfsburg work for VW, one of its subsidiary companies or suppliers. As the major tax payer in the region, benefactor to multiple 'good causes', sponsor and organizer of cultural events, owner of a major housing company, and investor in schools and nurseries, the company exercises profound influence throughout the city and the Federal State of Lower Saxony (Neue Schule Wolfsburg, 2009; Volkswagen Immobilien, 2014). VW dominates local media, the company's power plant provides electricity to part of the city, and its four colossal chimneys are the metropolitan area's most notable landmark. Wolfsburg is, in short, a contemporary 'company town' and its populace, for the most part, willing participants in its cloying embrace.

A substantial literature has established that control in organizations is significantly accomplished through processes of identity regulation in which employees desired identities are shaped profoundly by dominant, official discourses (Alvesson and Willmott, 2002; Grey, 
1994).These studies have greatly expanded our understanding of how corporate systems for performance management, appraisal, training and cultural engineering are means by which people are co-opted into panoptic systems of control and made to conform to specified norms by being surveilled, targeted and corrected (Covaleski, Dirsmith, Heian, and Samuel, 1998). This research has also shown how individuals are often complicit in their own subjection, engaging in identity work to formulate, maintain, adapt and repair selves in ways consonant with and supportive of the regime of power in which they are embedded (Foucault, 1977; Grey, 1994). A wealth of case studies demonstrate the means by which senior executives are able to tighten the iron cage through processes of corporate colonization to manufacture obedient employees (e.g., Barker, 1993; Burawoy, 1979), and, complementarily, the varying scope people in different contexts have to contest and resist them (Fleming and Spicer, 2003).

Considerable attention has been given in these studies to the writings of Foucault on disciplinary power relations, while, strikingly, his work on biopower and governmentality have received only lukewarm interest from identity scholars (Munro, 2012). Moreover, much attention has been devoted to organizationally based discourses and their implications for control through identity regulation; yet, discourses produced by other institutions and the interconnections between such discourses and those that are organizationally-based, have been under-studied in identities research. Recognition of the 'risks' of focusing narrowly on the formation of identities within organizations, and 'of failing to see the human individual as a "whole person"' (Watson, 2009: 426), has increasingly led researchers to look to the 'external, social, cultural context within which organizations are embedded' (Jelinek, Smircich, and Hirsch, 1983: 338). Our study complements and extends scholarship that has sought to analyse the broader discursive 'frameworks' in which organizations and identities are enmeshed (Clegg, 1989). It is a response also to exhortations to explore later works of Foucault on 
governmentality and biopower (Fleming, 2014; Hatchuel, 1999; Munro, 2012) in studies of identities to understand the nexus of power relations that characterize neoliberal contexts and shape the conduct and the identities of individuals.

Our research is an in-depth case study of Volkswagen's headquarters in Wolfsburg, a renowned company town. Company towns are traditionally defined as settlements built around a single enterprise in order to accommodate its employees (Garner, 1992; Green, 2012), where company control is extended beyond formal organizational boundaries into 'the private world of family and daily life' (Borges and Torres, 2012: 11). By investigating the formation of desired identities in the company city of Wolfsburg, we add to extant literature in two ways. First, drawing on Foucault's notion of governmentality in neoliberal societies, we examine mechanisms of power that make being a VW employee a desired identity for the city's populace. We argue that desired work identities, once embedded in a locality, are a mechanism by which a dominant organization exercises control over the entire population. Second, through analysing the multiple interlocking discourses produced by city institutions, which allowed VW to 'control the possible field of action' (Foucault, 2000: 341) of Wolfsburgers, we argue that governmentality of desired identities was made possible through the intermeshed functioning of discipline and biopower. We show that in contemporary times, the analysis of how employees desired identities form requires the study of the wider context in which neoliberal governmentalities shape employee aspirations and conduct. In doing so, we highlight the significance of company towns as contexts for the study of identity. 


\section{Company towns and desired identities}

\section{Company towns}

Defined as settlements 'built and operated by a single business enterprise' (Garner, 1992: 3) two principal forms of 'company town' dominate the literature. Traditionally regarded as temporary pioneering devices for opening-up unexploited territory and resources, they have been characterized most often as 'a frontier-style method of social and economic organization' (Porteous, 1970: 129) and associated with 'continuous misery among workers and numerous revolts' (Ehsani, 2003: 374). There is a substantial literature on these company towns, also sometimes referred to as monotowns, under conditions of European state socialism (Domanski, 1992), in ex-Communist countries such as Russia (Morris, 2015), and in developing countries like India (Sanchez, 2010). This corpus has shown how company towns are cohered by rationalizing and legitimating discourses (Sanchez, 2012) and characterized by paternalism which enshrines 'inequalities in life chances' (Domanski, 1992:353) and leads often to 'meaninglessness and alienation' (Morris and Hinz, 2017:289) among workers.

In contrast are company towns developed using the services of 'professional elites' under the influence of socially conscious, philanthropic and sometimes utopian discourses, for example, by Wedgwood, Cadbury, and Lever. Mostly a phenomenon of Western Europe and North America, they tend to be considered historical relics. Indeed, it is tempting to regard the 'company town' in the West, as being of largely historical significance. This, however, is to overlook the common modern phenomenon of the partial or pseudo company town that while notionally politically independent is nevertheless '...subtly influenced or controlled...by a single corporation which usually provides directly or indirectly, the bulk of local employment' (Porteous, 1970: 130). Recently, it has been argued that there has been a re-emergence of the company town model in the US with corporations such as Google and Facebook investing 
heavily in their locality in efforts to extend their influence over employees' lives (Borges and Torres, 2012).

Company towns are sites where a single organization with 'monopoly ownership' is able 'to impose its singular will on the urban space' (Ehsani, 2003: 362). It has long been recognized that in these circumstances control may be exercised transparently through housing and remuneration, and more subtly by manipulating local politics, organizing school curricula, dictating buying habits, administrating where people worship and directing how they spend their leisure time (Borges and Torres, 2012). Complementarily, commentators have noted that while ostensively designed to produce a workforce that is loyal, skilled, efficient and happy, in company towns controlling practices tend also to produce workers who are docile and lack individuality (Porteous, 1970). Despite observations which suggest that company interests are pursued through quasi- 'colonial practices and mechanisms' (Ehsani, 2003: 392), to achieve what Porteous (1970:131) refers to as 'the socio-religious moulding of the worker', relatively little attention has been devoted to company towns as regimes of power. Moreover, the literature on company towns is 'heavily dominated by local, economic, and business historians' (Porteous, 1974: 410), and although sociologists have also attended to their unique characteristics (Garner, 1992; Green, 2012; Sennett, 1980; Smith, Child, and Rowlinson, 1990) business and management scholars have shown remarkably little interest in them.

\section{Governing desired identities: Discipline and biopower}

Conceived as 'the meanings that individuals reflexively attach to themselves' (Brown, 2015: 23) considerable research has focused on people's subjectively construed identities and how these are made through processes of identity work (Bardon, Brown, and Peze, 2017; Lam, 2019; Sveningsson and Alvesson, 2003; Watson, 2009). Identity work refers to those linguistic 
and other symbolic means by which individuals - in relation to others - shape, adapt, maintain and repair sufficiently coherent and distinctive, but nevertheless always in-progress versions of their selves that maintain self-esteem and '...make oneself acceptable and respectable to others' (Ybema et al., 2009: 306). Particular attention has been paid to the formation of a desired identity as one that an individual strongly wishes or yearns for. This is reflected in studies of people's construction of 'preferred' (Kuhn and Nelson, 2002), and 'aspirational' (Thornborrow and Brown, 2009) selves fabricated from a range of 'possible' (Markus and Nurius, 1986), 'potential' (Gergen, 1972), and 'provisional' (Ibarra, 1999) options. In contemporary for-profit organizational contexts, desired identities are often bound-up with notions of 'individual self-fulfilment and self-achievement' (Beck and Beck-Gernsheim, 2002: 22), 'upward mobility and material accumulation' (Collinson, 2003: 503), and the construction of a notionally 'successful' career (Grey, 1994). While valuable, not all this theorising, especially that embedded in mainstream social psychology, has sufficiently recognized that how people construct their selves and who people say they want to become are effects of power.

We draw on the burgeoning literature on how organizations regulate the desired identities of their members through processes of normalization and surveillance associated with, for example, performance appraisal systems, management development practices and programmes of culture change (Alvesson and Willmott, 2002; Covaleski et al., 1998). Taking as their point of origin Foucault's (1977) understanding of disciplinary power as a means for creating obedient bodies, these studies demonstrate how identity regulation is enacted through discourse and practices which establish panoptic control by promoting norms to which individuals, by being targeted, adjusted and corrected, are made to conform (Grey, 1994; Thornborrow and Brown, 2009). Responding to these disciplinary mechanisms, people undertake conformist identity work, introspecting, constituting and articulating versions of their selves using the 
discursive resources made available to them and sanctioned by the organization such that each individual 'becomes the principle of his own subjection' (Foucault, 1977: 202-203). Identities, though, are not merely ascribed. While acceptance of a disciplinary regime is the price paid for realizing a desired identity, yet discourses and practices are more often 'appropriated' by reflexive individuals in bricolaged processes of self-fabrication in frameworks 'of selfdiscipline and self-knowledge [partially] of their own making' (Starkey and McKinlay, 1998: 231).

Foucault's later research work shows a shift from disciplinary power to a new form that he referred to as biopower (Foucault, 1978, 2000, 2008). He observed that discipline alone could not explain the contemporary growth of national and international markets and the rapid development of capitalist society (Fleming, 2014; Lorey, 2006; Munro, 2012). If disciplinary technologies function as mechanisms for the training and production of docile and productive bodies, biopower plays a similar role at the population level. Foucault argued that the mechanisms of biopower with its system of 'controlled insertion of bodies into the machinery of production and the adjustment of the phenomena of population to economic processes' was an indispensable element in the development of capitalism (Foucault, 1978: 141). In contrast with discipline, the function of which is to enclose, to confine and to determine segments, biopower has centrifugal characteristics (Munro, 2012), tending to expand through 'infrapolitical means, by enrolling our wider life practices, be they private interests, independent social abilities and personal aptitudes' (Fleming, 2014: 3). It integrates various elements, such as 'production, psychology, behavior, the ways of doing things of producers, buyers, consumers, importers, and exporters, and the world market' (Foucault, 2007: 67). Rather than contradicting each other, disciplinary and biopower co-exist: 
'This technology of power (biopower) does not exclude ... disciplinary technology, but it does dovetail into it, integrate it, modify it to some extent, ... embedding itself in existing disciplinary techniques' (Foucault, 2003: 242).

The concept of biopower focuses attention on governmental regulation of the life of a population (Foucault, 2007; Munro, 2012; Alawattage and Wickramasinghe, 2018). As Foucault explains, under neoliberalism the state gains its legitimacy on the basis of its economic performativity and the marketization of the state and its institutions (Flew, 2015; Gane, 2012) and the governmentality of individuals is made possible through the cooperation of different economic protagonists in this apparatus:

'The economy produces legitimacy for the state that is its guarantor... It produces a permanent consensus of all those who may appear as agents within these economic processes, as investors, workers, employers, and trade unions. All these economic partners produce a consensus, which is a political consensus, inasmuch as they accept this economic game of freedom' (Foucault, 2008: 84).

Governmentality describes the different ways that 'the conduct of individuals or of groups can be directed' (Foucault, 2000: 341). It focuses attention on the 'structural entanglement' of different institutions (Lorey, 2006: 1210) and how these concomitantly extend control over people's lives. Through technologies of governmentality authorities of various sorts seek to 'shape, normalize and instrumentalize the conduct, thought, decisions and aspirations of others in order to achieve the objectives they consider desirable' (Miller and Rose, 1990: 8). It works by acting upon 'the market milieu' in which the individual homo oeconomicus makes his or her decisions, in order to guide people towards economically and socially desirable behaviours (Foucault, 2008; Munro, 2012). Within neoliberalism, homo oeconomicus is conceived as an 'entrepreneur of the self' (Grey, 1994: 480), the living embodiment of 'human capital' (Munro, 
2012: 348). In response to such mechanisms, individuals must learn to develop a relationship with their self that is 'creative and productive', a relationship in which it is possible to fashion their “"own” body, "own” life, “own” self” (Lorey, 2006: 123). Hence, the modern notionally 'free' individual is compelled to produce themselves through and within such relations of power that dictate how the self under such systems should 'be'.

The literature on identity and in particular, on the formation of desired identities is to a large extent focused on discourses located within organizations (Jelinek et al., 1983; Watson, 2009). As Kuhn (2006: 1342) has observed, 'studies ... rarely attend to discourses beyond the artificial boundaries of the organization'. Although a stream of 'contextualist research' (Kondo, 2009) has focused on elements salient in social identities, such as culture, race, gender and age (Kondo, 2009; Thomas, Hardy, Cutcher, and Ainsworth, 2014), the literature predominantly ignores the role of interlocking discourses produced by various institutions outside of the work organizations that shape employee identity. Drawing on Foucault's $(2000,2008)$ work on governmentality, we contribute to extant literature by demonstrating how extra organizational discourses in contemporary neoliberal societies construct individuals' identities in combination with the discourses produced by work organizations.

While some organizational scholars (Knights and McCabe, 2003; Rasmussen, 2010) have previously employed the concept of governmentality to produce sophisticated analyses of people in organizations, these have nevertheless tended to focus on the microphysics of power and techniques of self-government rather than the multitude of socio-economics, communal and political discourses that individuals draw on in the construction of selves (Fleming, 2014). By analysing how institutions beyond the boundaries of work organizations, such as trades unions and local government reach consensus with the former to control the conduct of 
employees, our study contributes to identity research by examining the simultaneous functioning of discipline and biopower in a company city to govern the desired work identities of a populace.

\section{Research design}

\section{Context}

This interpretive, in-depth case study was devised to explore issues of identity regulation and identity work in the context of a specific company town. Founded on 1st July 1938, Wolfsburg, initially called "Stadt des KdF-Wagens bei Fallersleben" (KdF being the abbreviation for the leisure organization of the National Socialists, Strength through Joy), spent the Second World War producing ammunitions and military vehicles using forced labour (Siegfried, 1987). After the war, the British military took control of the city, re-named 'Wolfsburg', and the car plant was reconstituted as a commercial enterprise. As VW developed so did the city, the success of both (in 2013 Wolfsburg was, reputedly, the richest in Germany $^{2}$ ) being intimately intertwined (Riederer, 2013). The dominance of VW within Wolfsburg is profound: in 2014 Wolfsburg had a working population of 77,360 and VW employed 70,000 personnel ${ }^{3}$. In addition to its car plant, in which the company had its own restaurants, coffee shops, bakeries and florists, VW owned the Bundesliga football club 'VfL Wolfsburg' and the city's prime tourist attraction, a 28-hectare homage to VW cars called 'Autostadt'.

VW was led by a 'management board' which (typical of German companies) was monitored by a 'supervisory board' with the power to hire and fire the management team and sign-off on all strategic decisions. Also influential was the company's Works Council (the main body through which the Trades Unions exercised power) that had rights established under the 'VWAct of 1960' and 'Works Constitution Act of 1972', and provided half the membership of the 
'supervisory board'. Unusually, VW was 20.2\% owned by the Federal State of Lower Saxony, which appointed a further two members of the company's 'supervisory board', tying the corporation into the local political infrastructure. Official discourses, prominent on the group's website, emphasized VW's commitment to its people and their development, and also 'innovation', 'sustainability', 'exemplary leadership', and the uniqueness of its twelve brands which included Audi, Bentley, Bugatti, Lamborghini, Porsche and Ducati. Critics of VW, however, whose views were circulated prominently following the so-called 'emissions scandal' $^{\text {, }}$, described the organization's culture as 'authoritarian' (The Guardian, 2015), its management practices as 'patriarchal' (Handelsblatt, 2015) and its business orientation as protectionist (Kröger, 2015).

\section{Data collection}

Herself a resident of Wolfsburg, from September 2014 to January 2015, the first author conducted 45 semi-structured interviews. All the interviewees were either current $(\mathrm{N}=37)$ or ex- $(\mathrm{N}=6)$ members of $\mathrm{VW}$, or had experience working for the organization as a contractor $(\mathrm{N}=2)$, and all had either been born in Wolfsburg $(\mathrm{N}=16)$ or had moved to it for work purposes $(\mathrm{N}=29)^{5}$. Starting with friends and acquaintances who worked at VW a snowball sampling method was employed to identify interviewees, with individuals chosen to ensure that a wide variety of different voices (old and young, male and female, blue-collar workers, junior midranking and senior managers) were captured. Participants were asked questions about VW as well as Wolfsburg, such as 'what do you like about VW?' 'What are the characteristics of a typical VW-employee?' 'How would you describe the role of VW in Wolfsburg?' Two versions (English and German) of the interview guide were used depending on the linguistic competence and preference of each interviewee. Herself fluent in both English and German, 
the German language version of the interview schedule was translated by the first author and then proofread by a native German speaker.

The interviews, all of which were audio recorded, were conducted in public places, such as cafés or restaurants, in people's homes, at the IG Metall ${ }^{6}$ office and inside the plant. Varying in duration between 30 and 90 minutes, with a mean of 48 minutes, the interviews were fully transcribed by the first author yielding 225,481 words of transcript data. All German language transcripts were proofread by a native German speaker. Interviews were coded in their original language and translated (from German into English) only when a quotation was deemed sufficiently interesting to be placed in a data file. On such occasions, the first author translated the entire paragraph in which the quotation was located and had it checked against the original text by a German-English Anglophone. Linguistic translations are not unproblematic, as they include 'creative practice[s] of transformation and difference' (Steyaert and Janssens, 2013: 138), involving 'decontextualization', which can result in a 'loss of meaning' (Meriläinen et al., 2008:592). To mitigate these limitations, the first author engaged frequently in lengthy discussions with the translator/proof reader.

Interview data were supplemented by a large number of informal conversations with the interviewees and others with whom the first author interacted on a daily basis in Wolfsburg. While not designed as an ethnography, the first author made detailed notes on her everyday experiences, and these fed-into the on-going research, helping to sensitize her to key issues. In addition, a range of documentation was collected, including Volkswagen's in-house newspaper, Wolfsburg's local newspapers, company press releases, and other articles, audio and video news records relating to VW and Wolfsburg. We also consulted various websites including those of Volkswagen and its subsidiary companies based in Wolfsburg, the city of 
Wolfsburg and other institutions, such as IG Metall. Multiple German federal acts regarding VW and its relationship with the unions and institutions such as the Government of Lower Saxony were also reviewed. These informal conversations, and documentary collection and analysis, continued until December 2017.

\section{Data analysis}

Analysis of the data was informed by our understanding, that language and discourse 'construct and give order to reality' (Maclean, Harvey, and Chia, 2011: 20). Indeed, 'Language, put together as discourses' (Alvesson and Karreman, 2000: 1127) is 'perhaps the primary medium of social control and power' (Fairclough, 1989: 3). Our analysis involved an iterative process of circling back and forth between theory and empirical data. We adopted a method of discourse analysis most associated with Foucault (Potter, 1997), and sometimes referred to as Foucauldian Discourse Analysis (FDA). Following Willig's (2001) guidelines, we read through our data looking for material relevant to issues centred on identity in relation not just to VW but broader cultural, social, historical, economic and political discourses. A large number of codes, such as 'VW employee prosperity', 'Works Council helps VW', 'non-VW employee envy' and 'family friendly city' were created. Once the initial coding of the data was completed, we combined, collapsed, replaced and discarded these codes to form more inclusive and coherent analytical categories. While we engaged in procedures that were relatively systematic, we recognize as Stake (2003: 93) asserts, that 'the criteria of representation ultimately are decided by the researcher'. However, we have sought to attend to variations in what was said and to resist simplification or merely to categorise data using established frameworks. 
As we engaged reflexively with our data (Learmonth and Humphreys, 2012) over a period of many months we began to focus on VW/Wolfsburg as a confluence of intersecting discourses produced both by VW and other institutions in the city that in combination led people to desire work identities as VW employees. Sensitized to these themes we completed analysis of the data in relation to extant literature through processes described by Alvesson and Skoldberg (2000) as recursive, discovered, turned, twisted and complemented. Ultimately, through processes of discussion and negotiation between the researchers, the three principal data sections 'Governmentality and desired identities', 'VW/Wolfsburg: A disciplinary apparatus' and 'Cracks in the system of control?' were forged, refined versions of which are presented next.

\section{Governmentality and desired identities}

\section{Intimate ties: The municipality and the union}

Interviewees discursively constructed their city as the dominion of its major employer that, they said, exercised considerable control over it. Residents' talked about VW/Wolfsburg as a single, unified, corporate-municipal entity dominated by VW and its economic interests. Employees who were almost always inhabitants of the city said that ' $V W$ is Wolfsburg and Wolfsburg is $V W$ ' (Artur) and maintained that 'you cannot make a separation between the city and $V W . .$. This [VW and Wolfsburg] is one single entity' (Guido). The conflation of VW with the city led to the corporate-municipal nexus being described as 'a small universe' (Dirk), 'a whole new world' (Eda) and 'a micro-cosmos' (Lenard) that was optimized for the benefit of VW. There was agreement that, in part because of its economic muscle - 'VW supports ... [city] projects through donations and other financial means' (Maike) - the company held considerable sway over the political life of Wolfsburg: 
'If Volkswagen shouts, politicians in the city hall run. If Volkswagen says we need space to build some buildings, city hall looks for suitable spaces. If Volkswagen says we need to accommodate all employees here, what do you think the city of Wolfsburg does?' (Artur).

It was reported that senior political and corporate personnel had strong personal relationships: '...you hear of the Mayor of Wolfsburg and the head of the plant sometimes playing golf with each other' (Nicolas). Brita maintained, that a new local airport at Waggum had been built solely for VW's purposes. Rene told how the city's road infrastructure had been modified specifically to accommodate the company's employees. As the head of the Works Council wrote '...one of our first tasks has been to... work together with the city government, churches and other institutions... Today, the whole system breathes with the same rhythm as the plant' (Volkswagen-Karriere, n.d.).

Cooperation between corporate and political elites was rendered visible in the aftermath of the emissions scandal following which city politicians vehemently supported VW's management. For example, a local newspaper reported the Mayor of Wolfsburg as having said:

'The trust that VW has gained through entrepreneurial success and social responsibility "must not be questioned". [...] I personally have a huge trust in the leadership of the corporation, the supervisory board, the board of management and the Works Council' (WAZ, 2015).

Further, intimate ties between senior executives of VW and trades union representatives serving on the Works Council were said to exist, and to have been forged in the relatively small community from which they were drawn, which meant that they were often bound by friendships and sometimes family ties. One consequence of this, people said, was that trades unions (the Works Council) did not serve as a counter-weight to corporate/managerial interests, but was supportive of them. Further, people maintained that in order to reduce resistance to 
managerially inspired change, potentially controversial initiatives were announced strategically by the Works Council: 'In recent years... it's been always the Works Council who announced bad news' (Nicolas). This was evident too when Osterloh, the head of the Works Council wrote to employees in the wake of the emissions scandal to inform them that their annual bonus would be significantly lower than in the preceding year:

'We have come to an agreement with the CEO, Mathias Müller' and the head of HR, Karlheinz Blessing that Volkswagen pays 3950 Euros as the bonus for the previous year [2015]. Throughout the negotiations Mathias Müller proved to be a fair negotiator' (Osterloh, 2016).

Moreover, stories told by employees of people being 'punished' by the Works Council for complaining about their work conditions highlighted that threats to the status quo were countered, and discontented employees disciplined, by union officials on behalf of VW. For example, an elderly colleague of Brita, she said, wrote to the Works Council, complaining about poor work conditions and some organizational policies and 'he was then sent to a production hall which is loud, the work there is very difficult, and he had to work in the threeshift system. He is 56 years old. They sent him there!' Similarly, Fabian argued that:

'...the only important thing for the union is to make sure that everything goes smoothly for the company'.

In sum, people in their talk constructed the ties between VW, local political elites and unions as strong, intimate and interlocking which functioned to promote corporate interests.

\section{Shaping desire: Social welfare and elitism}

In Wolfsburg, interviewees said, it was a normalized expectation that people wanted to work for VW: 
'I think it's a goal in Wolfsburg to get into VW because it's considered here as normal to work for Volkswagen' (Nora).

The kind of identity that Wolfsburgers often wished to assume was generally not linked to a particular job within VW, or the attainment of a senior position in the corporate hierarchy: merely being a VW employee was what most people desired. This desired self was sustained by multiple interrelated and overlapping discourses centred on social welfare and elitism. VW was described as devising social welfare strategies that made it the employer of choice. Official discourses at VW emphasized that 'by 2018 VW wants to become the most attractive employer in the automobile industry' (Volkswagen Group, 2007), and these sentiments were echoed by VW managers:

'...we want to be the most attractive employer. This simultaneously means the most family friendly employer since we cannot forego any potentially engaged and well-educated mother or father' (Neumann, the former Head of the VW corporation's HR, Volkswagen-Karriere, n.d.).

Among the most frequently talked about aspects of VW's social welfare policies were job security, opportunities for self-development, job change and growth, flexible retirement options, health care, and study leave. Often these were said to be exclusively offered by VW: 'Volkswagen is a social partner. The job is much secured. There are so many social benefits that VW offers ... no other company in this area is able to offer such things' (Torben).

The span of VW's social welfare extended into domestic life, most notably through its family policies that were, arguably, a mechanism by which women in particular were co-opted into being working mothers who contributed directly to the productivity of VW while simultaneously producing the next generation of its employees. In addition to flexible working 
practices and VW's arrangements with nurseries to alter their working hours in line with the working shifts at the plant, the most obvious of these were VW seminars (VolkswagenKarriere, n.d.), conducted to mostly teach women how to manage their families while developing their careers. Rooted in a traditional view of the role of women in families, such measures exercised a form of ideological coercion over the domestic lives of employees and their families.

The desire to be a VW employee was connected, people said, to an understanding that working for the company meant that an individual was financially well-off and (somewhat relatedly) enjoyed a relatively higher status (was an 'elite') compared with non-members. For some, being well paid was the most important reason Wolfsburgers aspired to work for VW:

'The first step toward this [emotional bond between VW and the Wolfsburgers] is the financial issues' (Ferdi).

High salaries were, it was said, paid not just to managers but the company's entire workforce, including manual workers:

'Here, even that worker who does the, so to say, most stupid work has a very very good financial situation. He can spend lots of money and can show off what he has; good flat, good clothing, good car, two to three times a year holidays' (Ben).

The desire for a VW identity was, people maintained, not solely a matter of money, but also status, and the sense of being 'privileged' that attached to working for the company:

'...when you are at $V W$, you have a privileged status, you are privileged' (Lenard).

'It has status to work for Volkswagen' (Merle). 
While VW employees themselves were also acutely sensitive to differences in status between those working on more and less generous contracts, the main focus of people's talk was the distinction they made between 'insiders' (VW employees) and 'outsiders' (everyone else): 'This is something special about this city. There is outside and there is inside .... When someone in Wolfsburg says she/he is inside, you don't need to ask "inside what?" It's completely clear that she/he is inside the [VW] plant' (Dirk).

People referred to Wolfsburg as class-bound ${ }^{8}$, with outsiders effectively discriminated against in shops and sometimes even in their dealings with local bureaucracy:

'...here is a two-class society. VW-employees receive discounts everywhere [in Wolfsburg]: for example, with a VW ID-card you get 10 Euros discount, or 10\% discount; everywhere VW is better. And because of this a two-class society has been created: ...VW-employees, or the good ones, and the unimportant ones' (Maike).

The internal/external distinction was a means of both differentiating the local populace and hierarchizing them, with non-VW residents subject often to humiliations, disparaging comments and not infrequently depicted as deeply envious of 'insiders' and as objects of pity. 'Outsiders' said:

'Sometimes I think when they (VW employees) see me with my 20-year old Mercedes, they want to collect money for me, because they feel pity for me. Yes, they look down on others' (Volker).

'Insiders' were clear that:

'If you cannot make it into VW, you are a failure' (Kaspar). 
In sum, people desired, interviewees said, to work for VW as a result of perceived self-interest (social welfare provision, compensation etc.) but also because of supposed status benefits that attached to being an 'insider'.

\section{Individual homo oeconomicus: Cars and desired identities}

Interviewees said that cars were signifiers of the status of VW employees:

'Cars are status symbols. I find it so strange here that people ask you [at work] "what is your car?" before you even get to know each other' (Merle).

VW products were referred to as 'celebrated' and 'great', and employees were expected to drive a brand of VW cars to demonstrate their loyalty:

I think if you work for the company (VW) you should definitely drive a brand of the corporation... It is like you work for Samsung and you have an iPhone. That's a no go in my opinion' (Lasse).

'I believe there is a pressure on people [who live in Wolfsburg] to use VW cars' (Thorsten).

A typical VW employee was described as 'bonded to the [VW's] products' (Henry) and driving 'a leased car, which he changes every six months' (Timothy). As a result, the streets of Wolfsburg, interviewees said, had become a showroom for advertising VW products. New VW cars acted as a signifier for the 'VW employee' and the demarcation between her/him and the 'outsider' other. As a commodity, they underlined the financial well-being of their drivers, and functioned as a symbol of their privileged status, reproducing discourses regarding the elite standing of 'VW employees' and the desirability of such identities for Wolfsburgers. In addition to being new and often latest models, leased cars, through their number plates, signified their drivers' contract ${ }^{9}$ :

'[from the license plates] you can tell if someone is tariff plus ... or if she/he is a level higher, means in management, or if you know someone has the management licence plate and then you 
see his wife's car with the particular licence plate, then you know he is actually in upper management ${ }^{10} \ldots$ So, you can clearly see at which level he is' (Nora).

Thus, did the license plate system turn cars into emblems of one's achievements and wealth (or lack of them).

\section{VW/Wolfsburg: A disciplinary apparatus}

\section{Socialization: Families and schooling}

Socialization refers to those processes by which people learn to accommodate to a social system (Van Maanen and Schein, 1979). The desire for a VW identity, for many, began from childhood through primary socialization discourses associated with family members who worked for and spoke positively about the company:

' $V W$ is a part of who I am because I was born in Wolfsburg and have grown up here. My father worked for 43 years at $V W$.... At home during birthday parties or Christmas time the whole family talked always about $V W^{\prime}$ (Torben).

The dominance of VW-centred talk in families, some suggested, had restricted the pool of possible selves (Markus and Nurius, 1986) available to them from their youth:

'[VW] is a part of me. I have grown up with VW. My grandparents worked at VW, my parents worked at $V W$, I work at $V W$, my siblings worked at VW. I don't know anything else .... That's why there was no other alternative for me. It was clear for me that one day I will work at VW' (Teo).

Some even maintained that their parents had, from an early age, sought deliberately to cultivate in them the desire to join VW: 
'My father can influence me really well... He told me once: "Do you want to do an apprenticeship in VW to become a logistics manager? These people are always wanted and there are only ten vacancies in Wolfsburg". So, then I knew that it's something a bit elitist' (Nora).

Further, it was recognized '... that many Wolfsburger parents like it that their children find a job at $V W^{\prime}$ (Deter). Guido, a parent whose children were now employed by VW spoke of his delight that he could now relax because ' $[\mathrm{I}]$ have this feeling that they are kept safe and that's obviously a good feeling'. In addition, VW was described as seeking strategically to inculcate the desire for Wolfsburgers to work for the company through secondary socialization practices, centred on education/familiarization. VW had long run an annual series of three one-week programmes for the children (ages 6-12) of employees in which they were allocated a mentor who showed them around the plant, a scheme that was embraced enthusiastically by workers: 'When my son goes to school I want him to do it because it's so wonderful. ... It will give my son a much clearer picture about the place I'm working in' (Anja).

More recently VW had initiated a new school, considered by some the latest ' gift from $V W$ to the city' (Fabian). Clear from the rhetoric of senior executives of the company was the intention for the school not merely to educate its own students, but to influence the entire education system of the region:

'As the top employer, we consciously take responsibility for the important issue of education. ... The New School in Wolfsburg will start working in August 2009. ... From the beginning, the school will be in an intensive exchange with other schools and educational institutions - from nursery to college of further education - in the city and in the whole region' (Neumann, the former Head of the VW corporation's HR, Neue Schule Wolfsburg, 2009). 
Interviewees were adamant that the school and in general the education system in Wolfsburg from nursery level upward was designed to produce (effective) VW employees:

'They state it officially that ... we invest in the future of our children because we want to have them as future workers of Volkswagen' (Sönke).

The school was also widely regarded as designed not merely to fabricate technically competent workers but a cadre of people with strong emotional attachment to VW:

'They (VW) don't want employees who just get to work and do the work without passion. They want people who live for the company. An employee who loves his/her job, works better. That's why they try to educate the next generation for themselves' (Alexandra).

The corporatization of the local education system was a specific means by which VW sought to mould the populace of Wolfsburg into 'skilled and efficient...human capital' (Ehsani, 2003: 375) who was aspired to work for Volkswagen.

\section{Surveillance}

To be in public, in restaurants, shops, driving, walking and with friends was to be exposed to the continuous surveillance of VW employees, so that, interviewees said, everyone was always effectively at work:

'It feels like you are always at work in Wolfsburg because everywhere you see Volkswagen' (Nicolas).

'You are in a way always at Volkswagen' (Michael).

Many expressed concerns regarding how surveillance intruded into their personal lives:

'... if I do it (get drunk) in Wolfsburg, on Monday perhaps three colleagues would tell me they know what I had done on Friday evening' (Lasse). 
' $V W$ is omnipresent here. When they (VW employees) go shopping, they meet their colleagues. When they go swimming, they meet their colleagues.... So even in their private life, they are confronted with Volkswagen' (Katrin).

Some said that the possibility of being noticed led them to modify their behaviour to conform to social norms and to be seen as a good employee:

'One day I felt unwell at work. I came home to rest... I regained my energy and felt much better. My wife then suggested that we go out for an afternoon coffee, but I rejected the idea. ... If my colleagues had seen me in a café drinking coffee with my wife, what would have they thought?' (Nicolas).

The sense of being continually observed was, people said, reinforced by the extent to which everyday life, talk with friends and relatives, object symbols and municipal iconography centred on VW. Almost everyone, including not just employees but their families, local businesses, and those who worked for suppliers of VW, had their lives regulated by the company's three-shift system and mandatory three-week holiday period. VW's buildings dominated the city skyline and employees wearing VW jackets with VW ID cards hung from their clothes could be seen almost everywhere in Wolfsburg. All of which meant that on a quotidian basis people's discourse centred on VW:

'Whoever you know works for Volkswagen. There is a point, where all the conversation topics revolve around Volkswagen. In the end, you have to talk about Volkswagen' (Eda).

The overwhelming dominance of VW, perhaps, explains why many critical and cynical comments or questioning of the status quo were generally carefully qualified by phrases such as 'but it's not VW's fault' (Katrin) ${ }^{11}$. It was in part through pervasive and continuous 
surveillance that VW exerted control over the private lives of its workers, normalizing their personal conversations, relationships and behaviours, reducing the scope for contest and diversity to sustain a corporatized social order.

\section{Cracks in the system of control?}

Not all commentary on VW was positive. As Foucault (1978: 95) notes: 'where there is power, there is resistance' so that 'surveillance systems are always incomplete, always incapable of delivering the compliant prisoners, workers, or citizens that they promise' (McKinlay, 2008: 522). For example, interviewees talked about family members and acquaintances who had decided against working for VW:

'... there are also people who say they don't want to be a VW employee and want to be different. I have seen examples of this in my [sports] team. Some say they don't want to work for VW' (Merle).

Among those employed at VW, some had tried to find an escape from the overwhelming presence of the company and constant surveillance of their fellow VW workers by leaving Wolfsburg or moving away from the city centre:

'Everyone who lives here works for the company (VW) and that makes it difficult to live here because you keep bumping into people with whom you work... So, I moved to Braunschweig a couple of months ago' (Lasse).

The movement of people away from the VW plant and in some instances out of Wolfsburg was significant not least because it demonstrates the limits of corporate control over workers, and the capacity of employees to create 'subversive spaces' (Ehsani, 2003: 392) or 'free zones' (Ehsani, 2003: 393) less subject to technologies of governmentality. 
Most recently, the emissions scandal provoked support for VW and its senior managers but also resistance among ordinary employees to 'business as usual' managerial discourses. Shortly after the scandal broke, a Facebook page was created by some VW employees entitled 'I stand by Volkswagen, no matter what happens' on which were posted supportive statements, often centred on the need to show solidarity with VW to promote individuals' economic selfinterests. However, it also became a platform for disgruntled employees to air their grievances. An employee living in a neighbouring district of Wolfsburg wrote under a post that thanked Winterkorn for his years at Volkswagen following his resignation ${ }^{12}$ :

'We are in the current situation thanks to him. His managerial style and his objectives have caused this... I don't feel any solidarity with Winterkorn but rather with my colleagues! At the end of the day, we have to pay for all of this' (Facebook, 2015).

Indicative of discontent were the comments of a production line worker who argued that management of VW should be held responsible for the scandal, and bear the financial consequences by forgoing their generous bonuses:

'The one who has buttered the bread, has to eat it and not us, who do a very difficult job every day in the best way we can' (ibid.).

Such comments symptomize Ehsani's (2003) argument that despite corporate use of 'colonial practices and mechanisms' (p.392) not even in company towns can a corporation 'manage to impose a full hegemony upon the place' (p.393) it creates.

\section{Discussion}

In this section, we discuss how our study contributes to understanding mechanisms of governmentality in neoliberal societies that function to shape the desired identities of 
individuals, and how disciplinary mechanisms work to maintain them. First, we draw on literature on biopower and governmentality (Foucault, 1978, 2000, 2003, 2008) to discuss how desired identities are cultivated for Wolfsburg's populace. Second, we argue, that discipline works in combination with biopower to make possible the governmentality of people's lives. We also highlight the importance of company towns as contexts for research on the governmentality of identities that underlines how the 'structural entanglement' of multiple institutions within contemporary societies shape and instrumentalize people's desires.

\section{Governing desired identities in a company city}

As Markus and Nurius (1986: 954) have argued:

'An individual is free to create any variety of possible selves, yet the pool of possible selves derives from the categories made salient by the individuals' particular sociocultural and historical context and from the models, images and symbols provided by the media and by the individual's immediate social experiences'.

VW/Wolfsburg was, people said, characterized by dense familial and friendship ties operating at the level of both ordinary citizens and political and corporate elites that had developed over 70 years, supported by legislative Acts and a shared heritage of economic success. As Foucault (2008) asserts, the governmentality of individuals under neoliberalism functions through a consensus between economic protagonists including the unions, the state and employers. The city of Wolfsburg, according to interviewees, was designed for the optimum comfort of VW employees, and VW's managers always enjoyed the full support of the trades unions (Workers Council) and the city administration. This consensus aimed at promoting VW's economic wellbeing and hence, the development of the entire apparatus of VW/Wolfsburg. This in turn, arguably, re-produced the discourses that shaped VW as the source of prosperity for the city and its citizens. 
Wolfsburgers' desired work identities were shaped and their choices constructed by local discourses that positioned VW workers as privileged, high status, prosperous, 'insiders' and which disparaged non-VW employees as less affluent, of lower status, insecure, objects of pity, 'failures', 'wannabes', and 'rejects' who were ('rightly') envious of those able to claim VW identities. The centrifugal practices of biopower (Fleming, 2014; Foucault, 2007) that shaped Wolfsburgers' lives influenced their wider life practices, for example in the form of discriminatory practices in retail outlets and in local government which benefitted VW employees. Thus were 'outsiders' made into 'second class' citizens, being subject to the unrelenting discourse of contempt, pity, disapproval, and subordinacy, which simultaneously served as a continuing reminder to 'insiders' of the advantages of conformity.

VW's car leasing programme together with the discourses which equated loyalty to VW with driving one of its brands, turned employees into consumers of the products they helped produce. The individual homo oeconomicus in neoliberalism is the 'living embodiment of 'human capital'' (Munro, 2012: 348). It is a capital which is 'inseparable from the person who possesses it' (Foucault, 2008: 224), a capital that reproduces itself to become the source of its own earning, and its own consumption (ibid). Through leasing the latest models of VW, employees contributed to the overwhelming presence of new VW cars on the streets of Wolfsburg, and promoted discourses on VW's excellence and the privileged status of its people. This system of neoliberal governmentality produced individuals who were 'entrepreneurs of the self' (Grey, 1994), acting within forms of 'regulated freedom' (Rose, 1999) and making economic and social decisions which advanced the objectives of the entire apparatus of VW/Wolfsburg. The homo oeconomicus of neoliberal contexts is an economic subject who is 'eminently governable' (Foucault, 2008: 270), being given autonomy to shape 
its self and its life within constraints imposed by dominant discourses and practices that insists on who one should be (Lorey, 2006).

Neoliberal governmentality is 'far more diffuse' than disciplinary technologies alone (Munro, 2012), and acts upon the very context, the very milieu in which the 'economic subject' performs and makes its decisions. As in the case of VW/Wolfsburg, the consensus between institutions such as the city administration, Workers Council, schools and retailers with VW shaped a context that reproduced the discourses which moulded the desires of Wolfsburgers for VW employee identities (Miller and Rose, 1990). In contemporary neoliberal societies, we argue, examining employees' identity formation, and the construction of subjects' aspirations and conduct, cannot be accomplished solely by analysing the intra-organisational discourses and disciplinary techniques of organisational mechanisms. Studies of neoliberal governmentalities are required to investigate how several authorities exercise control over subjects through 'interventions upon the milieu' (Munro, 2012) in which employees perform and their identities are shaped.

\section{VW/Wolfsburg: A disciplinary apparatus}

The governmentality of individuals' lives and the formation of their desires was in Wolfsburg enabled in a system of discipline, where bodies were trained, and deviations were revealed through mechanisms of surveillance. As Foucault put it, discipline means 'adjusting power mechanisms to the individual body by using surveillance and training' (1978: 250). People said that while resident in Wolfsburg they were always 'at work', that conversations focused inexorably on VW, that they were prone continuously to the surveillance of other VW employees, and that this encouraged both compliance and quiescence. The exercise of disciplinary power was 'essentially corrective' (Foucault 1977: 179) aimed at disappearing 
disobedience by rewarding conformists and taking retributive action against outsiders and the recalcitrant either through processes of stigmatization and exclusion, or by depriving them of financial rewards. Schools, nurseries and VW's children supervisory programmes aimed to shape individuals who were interested in working for VW, through constraining their pool of possible selves (Markus and Nurius, 1986). Using surveillance and socialisation mechanisms the disciplinary techniques in Wolfsburg were centred on bodies, 'produc[ing] individualizing effects, and manipulat[ing] the body as a source of forces that have to be rendered both useful and docile' (Foucault, 2003: 249).

However, Wolfsburgers were not unreflexive, suggesting that the regime of surveillance was incomplete. As Foucault put it: 'it is not that life has been totally integrated into techniques that govern and administer it; it constantly escapes them' (1978: 143). Our research participants also acknowledged that VW/Wolfsburg was a closed, hierarchical universe and that the choices they made were circumscribed by the company's rules and its operational needs. Much has been written about the ability of individuals "to "make a difference" to the pre-existing state of affairs or course of events' (Giddens, 1984: 14). Foucault, for instance, is clear that power relationships always carry 'the recalcitrance of the will and the intransigence of freedom' (1982: 790) and that 'there are no relations of power without resistance' (1980: 142). Almost all participants in our study had their complaints, some had chosen not to work for VW, others had moved home to create distance between them and the company and one had exited VW. Nonetheless, to reside in Wolfsburg was to be subject to discourses that were associated with most people desiring a VW work identity, speaking enthusiastically and supportively about the company, delighting in driving its cars, and encouraging their children to grow up wanting to join the corporation. 


\section{The company city as a space for governmentality}

Foucault (2003) argued that discipline and biopower do not contradict but dovetail into and complement one another. The governmentality of desired identities was in the apparatus of VW/Wolfsburg the result of a 'diversity of regulatory mechanisms' (Miller and Rose, 1990:1) that shaped subjects whose conduct and aspirations promoted the economic prosperity of the entire apparatus. While for clarity of analysis we discussed these regulatory mechanisms separately, the macropolitics of power, established through practices of biopower, were embedded in micropolitical disciplinary practices which produced docile bodies. An example of this was the schooling system, where the corporatisation of education was facilitated by the local government and operated to constrain the 'pool of possible selves' (Markus and Nurius, 1986) of Wolfsburgers while educating docile bodies and manufacturing 'useful' future employees for VW. The integration of these technologies of power, which resulted in the governmentality of desired identities, was enabled within a spatial context, that is, the company city. As Foucault put it, all practices of governmentality are 'internal to the state or society' (2000: 91), and subjects become relevant to government interventions only when they enter the social and territorial space in which specific technologies of governmentality can be practised (Foucault, 2003, 2007, 2008). The city provides the spatial context wherein the discourses produced by the local government and its institutions, the union and the company combine to lock the city's inhabitants into certain conducts, decisions and aspirations. VW/Wolfsburg formed a complex equilibrium of economic, political and social forces (Foucault, 2003) which produced subjects with 'self-regulating capacities' that in turn were 'vital resources and allies' (Miller and Rose, 1990; Foucault, 1977) in reinforcing the 'adjustment of ... the population' (Foucault, 1978: 141) to the processes that ensured the economic well-being of the company. 
We have argued that desired work identities, once embedded in a locality, are a mechanism by which a dominant organization exercises control over a populace. From the early emergence of practices of biopower, spatiality, i.e. the context in which a 'population' as the subject of biopower is defined and regulated (Foucault, 2007), has had a significant role in technologies of governmentality (Munro, 2012). While company towns may not be 'representative' of contemporary Western cities, they provide a useful spatial context for studies of neoliberal governmentality due to the specific importance of a single corporation in the economic and political life of the city and its inhabitants. This unusual characteristic results in the vivid demonstration of the functioning of biopower in neoliberal contexts, the interconnectedness of public institutions and commercial work organizations and the consensus between these that results in governmentality of contemporary individuals. As Clegg et al. (2006: 143) argue, investigating the unusual is important for social science, because it 'serve[s] to demonstrate that irruptions to normalcy and taken-for-granted assumptions are not some deviation from normal, but regular albeit unpredictable, occurrences'. This study underscores the significance of company towns for identity research as they permit examination of the mechanisms of control and regulation that shape the identities of employees both at the level of individuals and populations. Moreover, research on company cities suggests the need to be sensitive to the wider contexts within which employees are embedded. As Watson (2009: 426) argues, 'there are dangers in the very notion of "constructing identity in organizations"” and a corresponding need to examine human individuals as 'whole' people. In the era of neoliberal governmentality, the identity, conduct, thought, decisions, aspirations and the entire life of the 'whole person' are shaped and instrumentalized in a milieu that authorities of various sorts seek to act upon. 


\section{Limitations and further research}

As with other single-site, exploratory research reliant mostly on discursive data, our findings are limited by the contextual, practical, methodological and analytical choices we have made. Our principal concern has been with discourses, and other studies that focus on institutional structures, legal frameworks and significant events (such as strikes) would complement our findings. We have given limited attention to the historical development of governmental forms of control in Wolfsburg and future research might usefully focus on their evolution. This is a time when conventional company towns are a significant element of rapidly industrializing economies (such as China, Russia and India), and large corporations worldwide are often seeking to extend their control over workers' lives. Our research suggests the need for organizational scholars to engage further with the multiple discourses and practices that discipline people's desired identities, narrowing their scope for autonomy and individuality, and rendering them in Marcuse's (1964) memorable phrase 'one-dimensional' men and women. Our study is important because it demonstrates how intertwined various institutions, such as families, cities, unions, schools and corporations can be, and how governmentality in neoliberalism is accomplished through intersecting discourses centred on them. In short, we hope that our research will motivate further studies of the analysis of biopower and the governmentality of individuals in neoliberal contexts, and the ways control operates beyond traditional organizational boundaries.

\section{Conclusions}

VW not only manufactured automobiles but regulated lives and disciplined individuals within the apparatus of VW/Wolfsburg to populate its plant. The cultivation of a desire for VW work identities was embedded and transmitted through multiple institutions - corporate, trades unions, familial and municipal/political - that regulated the conduct and aspirations of 
Wolfsburgers in ways consonant with dominant corporate-economic requirements. These processes were supported by mutual surveillance and discourses which discriminated against 'outsiders' and constituted VW employees as an elite who were privileged, successful and happy. What was at stake in VW/Wolfsburg was the entire life abilities, including intra- and extra-work qualities (Fleming, 2014), that were regulated to satisfy the VW/Wolfsburg apparatus. However, control is never total. The elements present in disciplinary systems are 'always open to unauthorized rearticulations' (Knights and Vurdubakis, 1994: 179). 'Insiders' voiced grievances and some had left the city to escape the omnipresence of the company. Despite this, it was an apparatus that functioned seemingly smoothly, in which discontents were rarely voiced, strike action all but unheard of, and employees insisted that they lived joyous and fulfilled lives. Such is the effectiveness of desired identities as means of control in processes of governmentality in neoliberalism.

\section{Notes}

${ }^{1}$ We use the terms 'town' and city' interchangeably.

${ }^{2}$ The Local. Retrieved 2001 2017. https://www.thelocal.de/20130729/51105.

${ }^{3}$ A small number of these resided in other cities.

${ }^{4}$ In September 2015, the Environmental Protection Agency (EPA) in the USA revealed that VW diesel cars sold in the United States were equipped with software installed in their engines, which could detect when the cars were being tested (and cheat them). Eventually, the company admitted that this software had been installed on more than 11 million cars worldwide (Hotten, 2015), and in June 2016, VW agreed with the US authorities to pay approximately $13.3 \mathrm{bn}$ Euros as compensation to American customers. The costs of product recalls and fines continues to mount (Zeit Online, 2016). 
${ }^{5}$ Formal access to the organization was attempted but abandoned as it became clear that VW would impose severe restrictions on the nature of the research and what could be published from it.

${ }^{6}$ The major union for the metalworkers in Germany.

${ }^{7}$ The CEO of Volkswagen Corporation from September 2015 to April 2018.

8 'Class' here does not refer to 'social class' as traditionally understood, merely to a subsection of the populace of Wolfsburg. Arguably, there has been an erosion of conventionally conceived 'class consciousness' over the late twentieth and early twenty first centuries that has made the neoliberal subject possible.

${ }^{9} \mathrm{VW}$ employees were categorized by their contracts (each of which had multiple tiers): 'tariff' (all blue collar workers, foremen and most white collar staff); 'tariff plus' (technical specialists and middle managers); and 'management', (a cadre of individuals who could be promoted through various grades of 'senior manager' culminating in board members). Each type of contract was associated with a different salary band and distinct privileges, including differential rights to lease new cars from VW.

${ }^{10}$ Those in the upper and top management levels could have a business car for their partners that has a specifically designed licence plate, demonstrating the managerial position of the driver's partner.

${ }^{11}$ This may also have been because those who were disaffected no longer lived in Wolfsburg or worked for VW.

${ }^{12}$ Shortly after the disclosure of the emissions scandal in September 2015, VW's supervisory board held a meeting and announced the resignation of VW's CEO, Martin Winterkorn. 


\section{Acknowledgments}

We thank Yiannis Gabriel for his helpful comments on an earlier draft of this paper, the Editorin-Chief, Nick Turner, and the four anonymous reviewers for their constructive feedback and thoughtful comments.

\section{Funding}

There are no funders to report for this submission

\section{References}

Alawattage C and Wickramasinghe D (2018) Strategizing management accounting: Liberal originis and neoliberal trends. Abingdon: Routledge.

Alvesson M and Karreman D (2000) Varieties of discourse: On the study of organizations through discourse analysis. Human Relations 53(9): 1125-1149.

Alvesson M and Sköldberg K (2000) Reflexive methodology: New vistas for qualitative research. London: Sage.

Alvesson M and Willmott H (2002) Identity regulation as organizational control: Producing the appropriate individual. Journal of Management Studies 39(5): 619-644.

Bardon T, Brown A D and Stephan Peze (2017) Identity regulation, identity work and phronesis. Human Relations 70(8): 940-965.

Barker J R (1993) Tightening the Iron Cage: Concertive control in self-managing teams. Administrative Science Quarterly 38: 408-437.

Beck U and Beck-Gernsheim E (2002) Individualization: Institutionalized individualism and its social and political consequences, Volume 13. London: Sage.

Borges M J and Torres SB (2012) Company towns: Concepts, historiography, and approaches. 
In: Borges M J, Torres S B (eds) Company towns: Labor, space and power relations across time and continents. New York: Palgrave Macmillan, 1-40.

Boussebaa M and Brown A D (2016) Englishization, identity regulation and imperialism. Organization Studies 38(1): 7-29.

Brown A D (2015) Identities and identity work in organizations. International Journal of Management Reviews 17: 20-40.

Burawoy M (1979) Manufacturing consent: Changes in the labor process under monopoly capitalism. Chicago: University of Chicago Press.

Casey C (1995) Work, self and society. London: Routledge.

Clegg S, Courpasson D and Phillips N (2006). Power and organizations. London: Sage.

Clegg S (1989). Frameworks of power. London: Routledge.

Collinson D (2003) Identities and insecurities: Selves at work. Organization 10(3): 527-547.

Contu A (2008) Decaf Resistance: On misbehaviour, cynicism, and desire in liberal workplaces. Management Communication Quarterly 21(3): 364-379.

Covaleski M A, Dirsmith M W, Heian J B and Samuel S (1998) The calculated and the avowed: Techniques of discipline and struggles over identity in big six public accounting firms. Administrative Science Quarterly 43(2): 293-327.

Domanski B (1992) Social control over the milltown: Industrial paternalism under socialism and capitalism. Tijdschrift Voor Economische En Sociale Geografie 83(5): 353-360.

Ehsani K (2003) Social engineering and the contradictions of modernization in Khuzestan's company towns: A look at Abadan and Masjed-Soleyman. International Review of Social History 48: 361-399.

Facebook (2015) Ich halte zu Volkswagen, egal was passiert [I stand by Volkswagen, no matter what happens]. Available at: https://www.facebook.com/pages/category/Automotive-Aircraft---Boat/Ich-halte-zu-Volkswagen-egal-was-passiert-1642791919360508/. 
Fairclough N (1989) Language and power. London: Langman.

Fleming P (2014) Review Article: When "life itself" goes to work: Reviewing shifts in organizational life through the lens of biopower. Human Relations 67(7): 875-901.

Fleming P and Spicer A (2003) Working at a cynical distance: Implications for power, subjectivity and resistance. Organization 10(1): 157-179.

Flew T (2015) Foucault, Weber, Neoliberalism and the Politics of Governmentality. Theory, Culture and Society 32: 317-326.

Foucault M (1977) Discipline and punish: The birth of the prison. London: Penguin Books. Foucault M (1978) The history of sexuality, Volume 1. London: Penguin Books.

Foucault M (1980) Truth and power. In: Gordon C (ed.) Power/Knowledge: selected interviews and other writings, 1972/1977. New York: Harvester Press.

Foucault M (1982) The Subject and Power. Critical Inquiry 8(4): 777-795.

Foucault M (2000) Governmentality. In: Faubion J (ed.) Power: Essential works of Foucault, 1954-1984. London: The New Press.

Foucault M (2003) Society must be defended: Lectures at the College de France 1975-76. New York: Picador.

Foucault M (2007) Security, Territory, Population: Lectures at the College de France 197778. London: Penguin Books.

Foucault M (2008) The birth of biopolitics: Lectures at the College de France, 1978-1979. Basingstoke: Palgrave Macmillan.

Gagnon S and Collinson D (2014) Rethinking global leadership development programmes: The interrelated significance of power, context and identity. Organization Studies 35(5): 645-670. Gane N (2012) The governmentalities of neoliberalism: Panopticism, post-panopticism and beyond. Sociological Review 60(4): 611-634.

Garner J S (1992) Introduction. In: Garner J S (ed.) The Company town: Architecture and 
society in the early industrial age. New York: Oxford University Press.

Gergen K (1972) Multiple identity: The healthy happy human being wears many masks. Psychology Today, 31-35, 64-66.

Giddens A (1984) The constitution of society: Outline of the Theory of Structuration. Los Angeles: University of California Press.

Green H (2012) The company town: The industrial edens and satanic mills that shaped the American economy. New York: Basic Books.

Grey C (1994) Career as a project of the self and labour process discipline. Sociology 28(2): 479-497.

Handelsblatt (2015) Matthias Müllers “Mission Impossible” [Matthias Müller's "Mission Impossible"], $\quad 25 \quad$ September. $\quad$ Available at: http://www.handelsblatt.com/unternehmen/industrie/neuer-vw-chef-matthias-muellersmission-impossible/12372242.html

Hatchuel A (1999) The Foucauldian detour: A rebirth of organization theory? Human Relations 52(4): 507-519.

Hotten R (2015) Volkswagen: The scandal explained. BBC, 10 December. Available at: http://www.bbc.co.uk/news/business-34324772

Ibarra H (1999) Provisional selves: Experimenting with image and identity in professional adaptation. Administrative Science Quarterly 44: 764-791.

Jelinek M, Smircich L and Hirsch P (1983) Introduction: A Code of Many Colors. Administrative Science Quarterly 28(3): 331-338.

Knights D and Clarke C (2014) It's a bittersweet symphony, this life: Fragile academic selves and insecure identities at work. Organization Studies 35(3): 335-357.

Knights D and McCabe D (2003) Governing through teamwork: Reconstituting subjectivity in a call centre. Journal of Management Studies 40(7): 1587-1619. 
Knights D and Vurdubakis T (1994) Foucault, power, resistance and all that. In: Jermier M J, Knights D and Nord W (eds) Resistance and power in organizations. London: Routledge.

Kondo D K (2009) Crafting selves: Power, gender, and discourses of identity in a Japanese workplace. Chicago: University of Chicago Press.

Kröger M (2015) Der König ist tot - wer braucht einen König? [The king is dead - who needs a king?]. Spiegel, 5 May. Available http://www.spiegel.de/wirtschaft/unternehmen/volkswagen-nach-ferdinand-piechkommentar-a-1029068.html

Kuhn T (2006) A "demented work ethic" and a "lifestyle firm": Discourse, identity, and workplace time commitments. Organization Studies 27(9): 1339-1358.

Kuhn T and Nelson N (2002) Reengineering identity. Management Communication Quarterly 16(1): 5-38.

Lam A (2019) Hybrids, identity and knowledge boundaries: Creative artists between academic and practitioner communities. Human Relations: 1-27. https://doi.org/10.1177/0018726719846259

Learmonth M and Humphreys M (2012) Autoethnography and academic identity: Glimpsing business school doppelgängers. Organization 19(1): 99-117.

Lorey I (2006) Governmentality and self-precarization: On the normalization of cultural producers. In: Sheikh S. (ed.) Capital: It fails us now. Berlin: Bbooks Verlag.

Maclean M, Harvey C and Chia R (2011) Sensemaking, storytelling and the legitimization of elite business careers. Human Relations 65(1): 17-40.

Markus H and Nurius P (1986) Possible selves. American Psychologist 41(9): 954-969.

McKinaly A (2008) Foucauldian turn. In: Clegg S and Bailey R (eds) International encyclopedia of organization studies. London: Sage.

Meriläinen S, Tienari J, Thomas R and Davis T (2008) Hegemonic academic practices: 
Experiences of publishing from the periphery. Organization 15: 584-597.

Miller P and Rose N (1990). Governing economic life. Economy and Society 19(1): 1-31.

Morris J (2015) Notes on the "worthless dowry" of soviet industrial modernity: Making working-class Russia habitable. Laboratorium 7(3): 25-48.

Morris J and Hinz S (2017) Free automotive unions, industrial work and precariousness in provincial Russia. Post-Communist Economies 29(3): 282-296.

Munro I (2012) The Management of Circulations: Biopolitical Variations after Foucault. International Journal of Management Reviews 14(3): 345-362.

Neue Schule Wolfsburg (2009) Die Ideengeber. Retrieved February 10, 2016. Available at: http://www.neue-schule-wolfsburg.de/unsere-schule/ideengeber. html.

Osterloh B (2016) Brief an die Belegschaft [Letter to the staff]. Mitbestimmen: Zeitung des Volskwagen Betriebsrates, May. Available at: https://www.igm-beivw.de/fileadmin/Material/Extrablatt_Brief_Bernd_Osterloh.pdf.

Porteous J D (1970) The nature of the company town. Royal Geographical Society 51: 127142.

Potter J (1997) Discourse analysis as a way of analysing naturally occuring talk. In: Silverman D (ed.) Qualitative research: Theory, method and practice. London: Sage.

Rasmussen J (2010) Enabling selves to conduct themselves safely: Safety committee discourse as governmentality in practice. Human Relations 64(3): 459-478.

Riederer G (2013) Die Barackenstadt: Wolfsburg und seine Lager nach 1945 [The barrack city: Wolfsburg and its camps after 1945]. Deutschland Archiv. Available at: http://www.bpb.de/geschichte/zeitgeschichte/deutschlandarchiv/riederer20130319/ Rose N S (1999) Powers of freedom: Reframing political thought. Cambridge: Cambridge University Press.

Sanchez A (2010) Capitalism, violence and the state: Crime, corruption and entrepreneurship 
in an Indian company town. Journal of Legal Anthropology 1(2): 165-188.

Sanchez A (2012) Deadwood and paternalism: Rationalizing casual labour in an Indian company town. The Journal of the Royal Anthropological Institute 18(4): 808-827.

Sennett R (1980) Authority. London: Secker and Warburg.

Siegfried K J (1987) Rüstungsproduktion und Zwangsarbeit im Volkswagenwerk, 1939-1945:

Eine Dokumentation [Armament production and forced labour in the Volkswagen plant, 19391945: A documentation]. Frankfurt am Main: Campus Verlag.

Smith C, Child J and Rowlinson M (1990) Reshaping work: The Cadbury experience. Cambridge: Cambridge University Press.

Stake R E (2003) Case studies. In: Denzin N K and Lincoln Y S (eds) Strategies of qualitative inquiry. London: Sage.

Starkey K and McKinlay A (1998) Afterword: Deconstructing organization-discipline and desire. In: McKinlay A and Starkey K (eds) Foucault, management and organization theory, from panopticon to technologies of self . London: Sage, 230-241.

Steyaert C and Janssens M (2013) Multilingual scholarship and the paradox of translation and language in management and organization studies. Organization 20: 131-142.

Sveningsson S and Alvesson M (2003) Managing managerial identities: Organizational fragmentation, discourse and identity struggle. Human Relations 56(10): 1163-1193.

The Guardian (2015) Volkswagen executives describe authoritarian culture under former CEO. Available at: https://www.theguardian.com/business/2015/oct/10/volkswagen-executivesmartin-winterkorn-company-culture.

Thomas R and Davies A (2005) Theorizing the Micro-politics of Resistance: New Public Management and Managerial Identities in the UK Public Services. Organization Studies 26(5): $683-706$.

Thomas R, Hardy C, Cutcher L and Ainsworth S (2014) What's Age Got to Do With It? On 
the Critical Analysis of Age and Organizations. Organization Studies 35(11): 1569-1584.

Thornborrow T and Brown A D (2009) 'Being Regimented': Aspiration, discipline and identity work in the British parachute regiment. Organization Studies 30(4): 355-376.

Townley B (1993) Foucault, power/knowledge, and its relevance for human resource management. Academy of Management Review 18(3): 518-545.

Volkswagen-Karriere (n.d.) Familie. Beruf. Ich. [Family. Job. I.]. Retrieved April 1, 2016. Available at: http://www.volkswagenkarriere.de/content/medialib/vwd4/de_vw_karriere/pdf/familienmanagementundberuf/_jcr_co ntent/renditions/rendition.file/familienmanagement_und_beruf.pdf

Volkswagen group (2007) Mach18. Retrieved March 14, 2015. Available at: http://www.volkswagenag.com/content/vwcorp/content/de/the_group/strategy.html.

Volkswagen Immobilien (2014) Kennzahlen [Key figures]. Retrieved January 15, 2014. Available at: https://www.vwimmobilien.de/unternehmen/ueber-uns/dasunternehmen/kennzahlen.html.

Watson T J (2008) Managing identity: Identity work, personal predicaments and structural circumstances. Organization 15(1): 121-143.

Watson T J (2009) Narrative, life story and manager identity : A case study in autobiographical identity work. Human Relations 62(3): 425-452.

WAZ (2015) Stürzt die Abgas-Affäre Wolfsburg in die Krise? [Does the emissions scandal throw Wolfsburg into a crisis?], 23 September, p. 14.

Willig C (2001) Introducing qualitative research in psychology. Berkshir: Open University Press.

Ybema S, Keenoy T, Oswick C, Beverungen A, Ellis N and Sabelis I (2009) Articulating identities. Human Relations 62(3): 299-322.

Zeit Online (2016) Der Abgasskandal [The emissions scandal], 18 September. Available at: 
http://www.zeit.de/wirtschaft/diesel-skandal-volkswagen-abgase.

\section{Biographies}

Elham Moonesirust is a Lecturer in Management Studies at the University of Aberdeen Business School. Her research interests centre on issues of identity, power, discourse and Critical Management Studies. [Elham.Moonesirust@abdn.ac.uk].

Andrew D. Brown is Professor of Organization Studies at the University of Bath. His work has been published in major journals including Academy of Management Review, Organization Studies, Journal of Management Studies, and Human Relations. He currently serves on the editorial boards of Organization Studies, Journal of Management Studies, and Organization, and he is an Associate Editor for Human Relations. [a.d.brown@bath.ac.uk]. 